\title{
The Effect of Picture Word Inductive Model (PWIM) on Students' Vocabulary Mastery
}

\author{
Kamarudin \\ English Language Education, Faculty of Culture, Management, and Business \\ Mandalika University of Education \\ Corresponding Author. Email: kamarudin.ntbe@gmail.com
}

\begin{abstract}
This research is aimed at finding out whether using Picture Word Inductive Model has positive effect on students' vocabulary mastery or not. The research was pre-experimental with pre-test post-test design. The population and sample of the study was second grade students of MTs NW Lingsar which consisted of one class (26 students). The instrument that was used objective test (20 items). The score was analyzed by used descriptive and inferential analysis. Descriptive analysis was used to describe mean; mode, median, and standard deviation of group, and inferential analysis was used to describe the value of $\mathrm{t}$ test for comparison between t-table. It was showed that the value of-test $=4.708$ was higher than the value of t-table $=1.708$. So, using Picture Word Inductive Model has positive effect on students' vocabulary mastery at MTs NW Lingsar.
\end{abstract}

Article History

Received: 12-04-2021

Revised: $12-05-2021$

Accepted: 22-06-2021

Published: 07-07-2021

\section{Key Words:}

Picture Word Inductive, Vocabulary.

How to Cite: Kamarudin, K. (2021). The Effect of Picture Word Inductive Model (PWIM) on Students' Vocabulary Mastery. Jurnal Paedagogy, 8(3), 288-295. doi:https://doi.org/10.33394/jp.v8i3.3851

\section{Introduction}

Mastering vocabulary is imperative in order to master four skills of language, such as listening, speaking, reading and writing. Thornburry (2002) revealed that without grammar very little can be conveyed, without vocabulary nothing can be conveyed. This is how linguistic David Wilkins summed up the importance of vocabulary learning. Vocabulary developments are not just learning more word knowledge. In expanding and Deeping word knowledge, the students are helped to increase what they know about words. Generally, vocabulary is the knowledge of meanings of words. What complicates this definition is the fact that words come in at least two forms: oral and print. Knowledge of words also comes in at least two forms, receptive that which we can understand or recognize and productive the vocabulary we use when we write or speak.

Read (2002) revealed that vocabulary knowledge is knowing the meaning of the words and therefore the purpose of vocabulary test to find out whether the learners can match each word with a synonym, a dictionary- type definition or an equivalent word in their own language. Moreover, Kamil \& Hiebert (2005) also stated that vocabulary is the meaning of unfamiliar word forms the text. Generically, vocabulary is the knowledge meanings of words. What complicates this definition is the fact the words come in at least two forms: oral and print. Knowledge of words also comes in at least two forms, receptive that which we can understand or recognize and productive the vocabulary we use when we write or speak. Furthermore, Nation (1990) took approach a step further by incorporating Ricards' assumption and several other components of word knowledge such as (1) From: Written from; students can write good word. (2) Position: Grammatical pattern; students can use good patterns in sentences. (3) Function: Appropriates; students can use appropriate words in good sentences, (4) Meaning: Concept; students can know meaning of words. 
Scrivener, (1994) divides vocabulary into two kinds, there are productive (active) vocabulary and receptive (passive) vocabulary. Productive vocabulary is the set of words that used in spoken communication. Good pronunciation might be encouraged getting the sound and the stress right. Receptive vocabulary is the use of words that we recognize and understand, but tend not to use ourselves. Thornbury (2002) reveals that there are 7 kinds of vocabulary, they are: Noun, verb, adjective, adverb, pronoun, preposition, and conjunction. There are four indicators of vocabulary, they are pronunciation, spelling, meaning, and using words (Thornburry, 2002; Brown, 2004; Rahmasari, 2021).

Learning English vocabulary is similar to learning other skills. The students should practice and do a lot of exercise, continually and seriously. In learning vocabulary, students also should be stimulated by using an interesting technique. If students lost interested in learning English vocabulary, it is impossible for them to study it interestingly. Therefore, the teacher should be competence in English vocabulary and also smart in choosing an appropriate method and media which can students' competence to learn English vocabulary.

Based on the observation within the teaching and learning process at MTs NW Lingsar, such problems were encountered by particularly when they learned English vocabulary items, such as difficult to memorize English words. It makes students become lazy, bored, sleepy, and not actively in the classroom.

So, one of the best methods to be applied in teaching English vocabulary is Picture Word Inductive Model (PWIM). This method is supposed to be suitable and fit for students since a lot of students were still lack of English vocabulary, as a result, they were difficult at speaking, understanding the reading passage, and even difficult at speaking practice. Calhoun, (1999) revealed that the PWIM is an inquiry-oriented arts strategy that uses picture containing familiar objects and actions to elicit words from children's listening and speaking vocabularies. This research is aimed at finding out whether using Picture Word Inductive Model has positive effect on students' vocabulary mastery or not.

\section{Research Method}

Research design is the preparation of the design of the research project (Kothari, 2004). The type of this research was experimental research with pre experimental design. This study inteded to know the effect of Picture Word Inductive Model on students' vocabulary mastery. In this research only one class, it meant without control group. Thus, the researcher used One-Group Pretest-Posttest Design. In conducting one group pre-test posttest design, the researcher gave the pre-test to students to found out the ability of students before getting the treatment, and then the researcher gave the treatment to the students. The treatment using "Picture Word Inductive Model", and the end the researcher gave post-test. The assessment needs to identify the effect of "Picture Word Inductive Model" in teaching vocabulary.

Population is all individuals of interest to the researcher (Marczyk, et., al, 2005). The population of this study was the whole students of the second-year students of MTs NW Lingsar who consisted of 26 students. Sprintall, (1991) revealed that sample is a smaller number of observations taken from the total number making up a given population. Since the number of the class was only one, and the number of the students was less than one hundred, then, the researcher took all the students as the sample.

The instrument of this research used objective test with multiple choices items which consisted of 20 items. There were 5 options ( $a, b, c, d$, and e). The total point for each item was 5 for the correct answer and 0 for incorrect answer. So, the total score of students who 
right in all number was 100 . To gain the data needed, this study applied some techniques of collecting the data, they were: (1) Pre-test, in the process of collecting the data, the researcher came to the class as a teacher. The researcher gave test as pre-test before explaining the material, it aimed to measure the ability of students in vocabulary before using "Picture Word Inductive Model (PWIM)". The test in the form of multiple choices with 5 options. The item consists of 20 items. (2) Post-test, before the researcher gave the students Post-test, the researcher gave treatment by using Picture Word Inductive Model. After the students given the treatment, the researcher gave Post-test to the students. The test was similar to the Pre-test, but different instruction. The test included 20 items of multiple choices that based on the materials that has taught in the treatment. The students selected one of the best answers. The scored of the students 5 for the correct answer and 0 the for incorrect answer.

After conducting the whole procedures of the data collection, it was then conducting the data analysis under some techniques of data analysis, they are;

1) Identifying the means score Pre-test and Post-test score

$$
M x=\frac{\sum x}{N}
$$

Where:

$\mathrm{M}=$ mean score

$\sum X=$ the sum of each of the values in the distribution.

$\mathrm{N}=$ the number of samples.

Arikunto, (2010)

2) Identifying frequency of distribution (mode)

Where:

$$
\mathrm{Mo}=\mathrm{L}+\mathrm{i}\left(\frac{r^{2}}{r^{1+r^{2}}}\right)
$$

$\mathrm{L}=$ the lower limit of the interval within which the mode lies

$\mathrm{I}=$ interval (class width)

$f_{i}=$ the frequency of the interval containing mode reduced by that of previous interval

$\mathrm{f} 2=$ the frequency of the interval containing mode reduced by that of following interval

3) Identifying frequency of distribution (median)

$$
\mathrm{Me}=\mathrm{L}+\mathrm{i}\left(\frac{\frac{\pi}{2}-c f o}{f w}\right)
$$

Where:

$\mathrm{L}=$ the lower limit of the interval within which the median lies

I = interval (class width)

$\mathrm{Cfb}=$ the cumulative frequency in all interval below the interval containing the median $\mathrm{fw}=$ the frequency of cases within the interval containing the median.

4) Identifying the student's individual deviation (d) of sample score.

$\mathrm{SD}_{\mathrm{D}}=\sqrt{\frac{\sum \mathrm{D}^{2}}{\mathrm{~N}}-\left(\frac{\sum \mathrm{D}}{\mathrm{N}}\right)^{2}}$

Where:

$\mathrm{SD}=$ standard deviation

$\mathrm{D}=$ the width. of deviation

$\mathrm{N}=$ the number of samples

$\sum \mathrm{D}^{2}=$ multiply of deviation 
5) Inferential Analysis

It was used to decide whether the results confirmed the predicted effects of the independent variable. In other words, this analysis draws the conclusion whether the scores between the pre-test and pos-test was significant and the using of Picture Word Inductive Model was effective or not.

The formula is shown as follows:

$$
\begin{aligned}
& t=\frac{\mathrm{md}}{\sqrt{\frac{\sum D^{2}}{N(N-1)}}} \\
& \text { Where: } \\
& \mathrm{md}=\text { Standard Deviation } \\
& \mathrm{N}=\text { the unit of sample } \\
& \sum \mathrm{v}^{2}=\text { sum of deviation quadrate. }
\end{aligned}
$$

\section{Finding and Discussion}

This part deals with finding and discussion of effectiveness of Picture Word Inductive Model on students' vocabulary mastery at MTs NW LIngsar. The finding and discussion are presented separately.

Finding.

This research was conducted on 18 August - 28 August at MTs NW Lingsar. The steps of the research were as follows: at the first meeting was on 18 August, the researcher gave Pre-test, the second meeting was on 21 August, and in $25^{\text {th }}$ of August the researcher treated the students by using Picture Word Inductive Modal. And the third meeting on was 28 August the researcher gave Post-test.

After giving the treatment and the test toward the students, the researcher found the following data.

Table 1. Data Computation: Pre- Test and Post- Test.

\begin{tabular}{lccccc} 
No & Name & $\begin{array}{c}\text { Pre-test } \\
(\mathbf{X} 1)\end{array}$ & $\begin{array}{c}\text { Post-test } \\
(\mathbf{X} 2)\end{array}$ & Score of Deviation (D) & Deviation Quadrate $\left(\mathbf{D}^{\mathbf{2}}\right)$ \\
\hline 1 & AI & 45 & 60 & 15 & 225 \\
\hline 2 & ARR & 35 & 60 & 25 & 625 \\
\hline 3 & BHD & 40 & 55 & 15 & 225 \\
\hline 4 & EVN & 30 & 45 & 15 & 225 \\
\hline 5 & HDJ & 50 & 65 & 15 & 225 \\
\hline 6 & HDH & 55 & 65 & 10 & 100 \\
\hline 7 & HST & 45 & 60 & 15 & 225 \\
\hline 8 & HWT & 35 & 50 & 15 & 225 \\
\hline 9 & HK & 40 & 45 & 5 & 25 \\
\hline 10 & IKR & 35 & 60 & 25 & 625 \\
\hline 11 & LPJ & 45 & 70 & 25 & 225 \\
\hline 12 & MA & 60 & 75 & 15 & 225 \\
\hline 13 & MDH & 45 & 60 & 15 & 400 \\
\hline 14 & MFYA & 50 & 70 & 20 & 625 \\
\hline 15 & MPR & 35 & 55 & 20 & 225 \\
\hline 16 & MR & 40 & 65 & 25 & \\
\hline 17 & MFI & 50 & 65 & 15 & \\
\hline
\end{tabular}




\begin{tabular}{lccccc}
\hline 18 & NY & 35 & 50 & 15 & 225 \\
\hline 19 & PA & 35 & 65 & 30 & 900 \\
\hline 20 & QJ & 30 & 45 & 15 & 225 \\
\hline 21 & RJ & 45 & 55 & 10 & 100 \\
\hline 22 & R & 35 & 50 & 15 & 225 \\
\hline 23 & RD & 40 & 60 & 20 & 400 \\
\hline 24 & SM & 30 & 65 & 35 & 1225 \\
\hline 25 & SLA & 55 & 80 & 25 & 625 \\
\hline 26 & ZR & 40 & 60 & 20 & 400 \\
\hline \multicolumn{2}{r}{ Total } & 1.080 & 1.555 & 475 & 9.775
\end{tabular}

The data presented above was then analysis statistically as follow.

a. The mean score

1. The mean score of pre-test

$$
\begin{aligned}
& M X_{1}=\frac{\sum X_{1}}{N} \\
& =\frac{1.080}{26} \\
& =41.53 \\
& \sum \mathrm{X}_{2}=\frac{2 f^{2} x_{1}}{N} \\
& =\frac{1.057}{26} \\
& =41.03
\end{aligned}
$$

2. The mean score of post-test

$$
\begin{aligned}
& M X_{1}=\frac{2 \tilde{a}_{1}}{N} \\
= & \frac{1 . b 5}{26} \\
= & 59.80 \\
& \sum \mathrm{X}_{2}=\frac{2 J_{1} X_{1}}{N}
\end{aligned}
$$

$=\frac{1.449}{26}$

$=57.65$

b. The mode score

1. The mode score of pre-test

$$
\begin{aligned}
& \text { Mo }=\mathrm{L}+\mathrm{i}\left(\frac{r^{2}}{r^{2+\tau^{2}}}\right) \\
& =32.5+5\left(\frac{30}{30+0}\right) \\
& =32.5+5(1) \\
& =37.5
\end{aligned}
$$

2. The mode score of post-test

$$
\begin{aligned}
& \text { Mo }=\mathrm{L}+\mathrm{i}\left(\frac{\tau^{2}}{t^{1+f^{2}}}\right) \\
& =59.5+6\left(\frac{4 \mathrm{~s}}{4 \mathrm{~b}+10}\right) \\
& =59.5+6\left(\frac{4 \mathrm{~s}}{b \mathrm{~s}}\right) \\
& =59.5+6(0.81) \\
& =59.5+4.86
\end{aligned}
$$


$=64.36$

c. The median score

1. The median score of pre - test

$\mathrm{Me}=\mathrm{L}+\mathrm{i}\left(\frac{\frac{\pi}{\mathrm{n}}-c t 0}{f w}\right)$

$=50.5+5\left(\frac{\frac{2 \text { 는 }-15}{3}}{3}\right)$

$=50.5+5\left(\frac{1 s-15}{3}\right)$

$=50.5+5(0.6)$

$=50.5+3$

$=53.5$

2. The median score of post - test

$\mathrm{Me}=\mathrm{L}+\mathrm{i}\left(\frac{\frac{\pi}{3}-c J D}{j w}\right)$

$=65.5+6\left(\frac{\frac{20}{2}-y}{2}\right)$

$=65.5+6\left(\frac{1 y-y}{2}\right)$

$=65.5+6\left(\frac{4}{2}\right)$

$=65.5+6(2)$

$=65.5+12$

$=77.5$

d. Standard Deviation

$\mathrm{SD}_{\mathrm{D}}=\sqrt{\frac{\sum \mathrm{D}^{2}}{\mathrm{~N}}-\left(\frac{\sum \mathrm{D}}{\mathrm{N}}\right)^{2}}$

$=\sqrt{\frac{9.775}{26}-\left(\frac{475}{26}\right)} 2$

$=\sqrt{375.96-333.76}$

$=\sqrt{42.2}$

$=6.49$

e. Inferential Analysis

$$
\begin{aligned}
& t=\frac{\text { md }}{\sqrt{\frac{\sum D^{2}}{N(N-1)}}} \\
& =\frac{18.26}{\sqrt{\frac{9775}{26(26-1)}}} \\
& =\frac{18.26}{\sqrt{\frac{9775}{650}}} \\
& =\frac{18.26}{\sqrt{15.0384615385}} \\
& =\frac{18.26}{3.87 / 4453306} \\
& =4.7086788239
\end{aligned}
$$


Table 2. Comparison of the t-test and t-table

\begin{tabular}{|l|l|l|}
\hline \multirow{2}{*}{ t-test } & \multicolumn{2}{|c|}{ t-table } \\
\cline { 2 - 3 } & Df $(\boldsymbol{N}-\mathbf{1})$ & $\mathbf{0 . 0 5}$ \\
\hline 4.7086 & Df $(26-1)=25$ & 1.708 \\
\hline
\end{tabular}

Based on the result of the t-test above, it was found that t-test was 4.7086, t-table was 1.708 and sig was 0,05 . It means that the t-test value was higher than the t-table. Based on this finding, the researcher also concluded that the alternative hypothesis (Ha) which stated that using PWIM has a significant effect toward students' vocabulary mastery was accepted and the null hypothesis (Ho) which stated that using PWIM has no significant effect toward students' vocabulary mastery was rejected.

Discussion

Regarding the result of the research after conducting some sequences of research procedures. the researcher answered the question intended; Is there any effect of Picture Word Inductive Model on students' vocabulary mastery?. This statement of the problem had been answered based on the research result above. Based on previous chapter, there were explained about the comparison between $\mathrm{t}$-test and t-table, where if $\mathrm{t}$-test is higher than $\mathrm{t}$ table. Therefore, Ha was accepted and Ho was rejected.

In previous chapter, it was analyzed that the value of pre-test and post-test of students' vocabulary mastery by using PWIM and inferential analysis. It was found that, the value of pre-test where mean score was 41.53 , mode score was 37.5 , median score was 53.5. Then the value of post-test where the value of the mean score was 59.80, mode score was 64.36, median score was 77.5, the standard deviation score was 6.49 , and inferential analysis were found that the value of t-test $=4.708>\mathrm{t}$-table $=1.708$. Based on the discussion above, the researcher concludes the use of PWIM has significant effect towards students' vocabulary mastery.

\section{Conclusion}

To clarify the result of this study, the researcher concluded whole the data found during research process. Based on the statistical analysis, the value of t-table was 1.708 from (df) 26 $-1=25$, it was clear that $\mathrm{t}$ - test was higher than $\mathrm{t}$-table. It means that the alternative hypothesis was accepted, meaning that there is a significant effect of PWIM toward students' vocabulary mastery at the second-grade students of MTs NW Lingsar.

\section{Suggestion}

It is suggested that teachers are highly suggested to apply PWIM strategy in their teaching and learning process particularly teaching English vocabulary so that the students do not feel bored in the class. As well as for the students, the students should ask the teachers if there is something that they don't understand within the teaching and learning process. Of course, becoming active students is also required to enrich English vocabulary items.

\section{References}

Arikunto, Suharimi. (2010). Procedure Penelitian, Suatu Pendekatan Praktik. Edisi Revisi, Jakarta: PT. Rineka Cipta.

Brown, H. Douglas. (2004). Language Assessment: Principles and Classroom Practices. San Francisco State University.

Coulhon, E. F. (1999). Teaching Beginning Reading and writing with Picture Word Inductive Model. Virginia USA: Alexandria. 
Kamil, L. M, Hiebert, H.E. (2005). Teaching and Learning Vocabulary Bringing Research to Practice. New Jersey: Lawrence Erlbaum Associates Publisher.

Kothari, C.R. (2004). Research Methodology. New Delhi: New Age International.

Marczyk, Geoffrey. (2005). Essential of Research Design and Methodology. New Jerney: Simulaneosly in Canada

Nation, I.S.P. (1990). Teaching and Learning Vocabulary. New York: Heinli and Heinli

Rahmasari, B. (2021). Improving Students' Vocabulary Mastery Through Bingo Games. Jurnal Kependidikan: Jurnal Hasil Penelitian dan Kajian Kepustakaan di Bidang Pendidikan, Pengajaran dan Pembelajaran, 7(1), 28-34. doi:https://doi.org/10.33394/jk.v7i1.2696

Read, John. (2002). Assessing Vocabulary. Australia Cambridge University Press.

Scivener, J. (1994). Learning Teaching: A Guidebook for English Language Teaching. The Bath Press.

Sprintall. R.C., Schmutte, T.G., \& Sirois, L. (1991). Understanding Educational Research. USA: Prentice-Hall.

Scivener, J. (1994). Learning Teaching: A Guidebook for English Language Teaching. The Bath Press.

Thornburry, Scott. (2002). How to Teach Vocabulary. England: Person Longman. 